Asia Pacific Journal of Advanced Business and Social Studies

ISBN (eBook): 9780994365675 I ISSN : 2205-6033

Year: 2018 , Volume: 4, Issue: 1

\title{
PUBLIC FINANCING PROGRAMS AND INDUSTRIES OF LOCAL PRODUCTIVEARRANGEMENTS AT ABC-SP AREA
}

\author{
Rebeca B. Lima a , Júlio F. B. Facó b ${ }^{b}$ Ricardo R. Jorge ${ }^{c}$, Alexandre A. de Andrade ${ }^{d}$ \\ abcd Universidade Federal do ABC, Brazil \\ Corresponding email: julio.faco@ufabc.edu.br
}

\begin{abstract}
In spite of their size, Micro and Small companies are also embedded in a highly competitive and dynamic environment. Hence, investments in innovation can play an important role for them to remain on the market. It is relevant to consider that these companies often face a lot of economic obstacles which include high costs and financial constraints. Regarding this situation, public funding programs can be a crucial alternative so that these companies can be able to invest in innovation. Therefore, this research analyzes Small Businesses with a focus on the Brazilian scenario, in order to better know the companies of their companies and their general characteristics. Moreover, the relationship of the theme with an innovation and those from the influence of business enterprises and public policies for innovation were evaluated for a policy of Science Technology and Innovation in Brazil and also highlight some types of clusters. This study analyzes government financial programs, which focus on innovation, regarding Micro and Small Enterprises in Brazil. In order to get acquainted with the innovation process from the arrangements and verify how they have been accessing and using the analyzed financial programs, this work also contains a survey including four Productive Companies of industries located at ABC region from São Paulo, Brazil. This lecture intends to show the impact and results that lack of appropriate financing resources and knowledge, along with high costs, they may have in the innovation process and growth of the examined companies.
\end{abstract}

Keywords: Financing, Innovation, Micro and Small Enterprises, Public Policies

\section{International Context}

\section{Small Business}

Small businesses have different classifications and impacts on the international scene, but in general, they are of great importance in the economies of the countries. The Global Entrepreneurship Monitor (GEM) showed that Small and Medium Enterprises (SME) contribution in countries' GDP varied between 9\% (India, followed by Chile, Senegal and Botswana with 20\%) and 99\% (Lebanon, preceded by Egypt with 80\%) (Global Entrepreneurship Monitor, 2016).

An important economy in the international scenario is the North American that has relevant surveys on SME. However, the U.S. International Trade Commission (USITC) points out that there is no universally accepted definition for SME, even within the United States, which is due to the difference between this classification for the different sectors (U.S. International Trade Commission, 2010). In the European Union, another benchmark, micro, small and mediumsized enterprises are characterized by stimulating entrepreneurship and innovation and are therefore crucial to boosting competitiveness and employment. 
In Brazil, small businesses are usually defined as Micro and Small Enterprises (MSEs) or Microenterprises and Small Enterprises, to define who these organizations are is not so simple, since there are different definitions and characterizations adopted within the country. The definition that can be considered the most adopted in the Brazilian scenario is in the General Law of Micro and Small Companies, as it is called the complementary law number 123/2006 of

December 14, 2006, which establishes the National Statute of Microenterprise and Small

Enterprise Porte. For microenterprises gross annuity revenues must be less than or equal to $\mathrm{R} \$$ 360000,00 , and for the Small Business Company, gross annual revenues must exceed $\mathrm{R} \$ 360$ o00,00 and less than or equal to $\mathrm{R} \$ 3600000,00$.

Another important definition comes from the Brazilian Service of Support to Micro and Small Companies (Sebrae), which classifies the size of the company considering the number of employees and the sector that it occupies. This specification can be seen in the following table:

Table 1: Size classification criteria of enterprises by employed persons

\begin{tabular}{c|c|c}
\hline \multirow{2}{*}{ Company size } & \multicolumn{2}{|c}{ Economic activities } \\
\cline { 2 - 3 } & \multicolumn{1}{|c}{ Services and Trade } & Industry \\
\hline Micro & Up to 9 people occupied & Up to 19 people occupied \\
\hline Small & $\begin{array}{l}\text { From 10 to 49 persons } \\
\text { employed }\end{array}$ & $\begin{array}{c}\text { From 20 to 99 persons } \\
\text { employed }\end{array}$ \\
\hline
\end{tabular}

Source: Brazilian Micro and Small Business Support Service (Sebrae)

It is essential to measure the role of MSEs in the Brazilian economy in order to identify their impact on the country and the importance of investing in them. According to Sebrae, in 2015, they already exceeded 9.5 million companies. In a study published by Sebrae, based on annual sector surveys of the Brazilian Institute of Geography and Statistics (IBGE), it was concluded that MSEs generated, in 2011, 27\% of the value added of the set of activities surveyed

(Gross Domestic Product - GDP), with 10\% in Services, 9.1\% in Commerce and 7.8\% in Industry. The value found is very expressive, since it indicates that in the period evaluated, they contributed with more than a quarter of the national GDP, confirming the importance of studying organizations of this size.

\section{Innovation}

Innovation does not have a closed concept that is globally accepted, but it is defined in the literature by several authors with aspects in common, the definitions may vary in theory, but all emphasize the need to complete the aspects of development and deepening of new knowledge.

However, in order to identify the process of innovation and to be able to size it, it is necessary to have parameters that are not completely subjective. In order to define such delimitations, the Organization for Economic Cooperation and Development (OECD) has developed the so-called Oslo Manual, which is currently in its third edition and widely adopted worldwide. It aims to provide guidelines for the collection and interpretation of data on innovation, orienting and standardizing concepts, methodologies and construction of Research and development (R \& D) statistics and indicators, especially for industrialized countries.

In the manual, innovation is defined as the implementation of a product (good or service), or process, or organizational method or marketing method that is new or significantly improved. The presence of the last two classifications was a novelty of the last edition, which also began to consider innovation in less $\mathrm{R} \& \mathrm{D}$ intensive segments such as services and the low-tech transformation industry, called "non-technological innovations. These changes were significant, 
but were given the freedom to increase or not in the surveys (Organização para Cooperação e Desenvolvimento Econômico, 2005).

When analyzing definitions for innovation in the national context, it is possible to observe that they are similar to those defined in the Oslo Manual and some have even it as a fundamental basis. As an example, we have the National Technological Research (Pintec), the NBR (Brazilian norm) 16500: Activities for the management of research, development and innovation Terminology and the Law 11.196 of November 21, 2005.

When discussing innovation in MSEs in Brazil, it should be considered that there is a lack of historical indicators and data that can demonstrate the managerial behavior of small enterprises, since only in the last decades have these companies gotten more attention from official bodies. Results of specific studies carried out with companies of this size help to understand a little of how innovation has been developed: When the main reasons for the incorporation of this process: economic, technological and social; When the propensity for innovation: low to moderate (with mature companies having the most effective results in the process); As for form: open innovation has proven to be an alternative for these companies that usually find it difficult to innovate in the traditional format due to the few resources and low capacity to invest in internal R \& D.

\section{Influence of Business Alliance and Public Policies for Innovation}

The 'coopetition' is an idea proposed by Branden burger and Nalebuff in the face of the perception that the pursuit of value by companies involves both cooperation and competition, and it is the combination of these two terms. According to Bouncken, Gast, Kraus, and Bogerscoo petition is not only a simple form of alliance, but describes the growing cooperative relationships between competing organizations, its research flow has incorporated strategies and other fields of forthcoming research as innovation, management and entrepreneurship.

Specifically relating to innovation, coopetition is seen as a strategy that can promote crucial benefits for its development.

According to the study by Gast, Filser, Gundolf, and Kraus, the innovation theme appears among the highlighted fields of action. On evaluating this theme, it was observed that there is generally a positive relationship between coopetition and innovation, but it is emphasized that generalizations need to be cautious since the result of cooperation in innovation is not always positive for all parties involved, thus potential risks and benefits should be carefully considered.

Another important concept are the clusters, that according to Porter, are geographic concentrations of interrelated companies, specialized suppliers, service providers, companies in related sectors and other specific institutions (universities, standards bodies and trade associations) that compete, but also cooperate with each other. It may be noted that some of the most important agglomerations economies represent dynamic efficiencies and revolve around innovation and learning speed.

In Brazil, it was created as a cluster-like concept, called Local Productive Arrangement (LPAs), defined by Cassiolato and Lastresas territorial agglomerations of economic, political and social agents (focusing on a specific set of economic activities) even if incipient. A competitive basis of companies in any productive arrangement is not restricted to a single sector, being strongly associated with activity and training back and forth along the production chain.

In relation to innovation incentive policies there are different theoretical perspectives when it comes to innovation and these cover the most varied disciplines. When the focus is on how innovation processes are developed in the regional or national spheres, a vision known as 'Innovation System' can be highlighted, which studies the influence of external institutions on innovative activities, considering a dynamic process in which the knowledge is accumulated 
through learning and interaction, it highlights the importance of the conditions, regulations and policies in which markets operate and, consequently, the role of governments in monitoring and seeking the harmony of that structure (Organização para Cooperação e Desenvolvimento Econômico, 2005).

In the 1950s, at the height of Brazilian industrial development, some isolated initiatives towards the construction of a National Innovation System in Brazil began to happen, and could be considered the beginning of the formulation of a national Science and Technology (S \& T) policy in Brazil. Until the end of the 1990s, the innovative efforts of Brazilian companies were very limited and the scope of measures, which were more palliative, began to run out and show the need for change. At the moment, a reform in S \& T policy is beginning to emerge, with a greater emphasis on innovation with the aim of promoting greater competitiveness of firms and sustainable economic growth.

\section{Methodology}

This study can be considered an applied research, as to its purpose, an exploratory research, as to its general objectives, and a mixture of Bibliographic Research and a Survey, as to the method used.

\subsection{Analysis of Investment Programs}

We analyzed the national programs focused on innovation that are currently in force and include small companies among the beneficiaries. A description of the programs was elaborated based on the information made available by the responsible organs, in their websites, circulars and edicts.

\subsection{Survey}

- $\quad$ Research instrument: For the field survey, a questionnaire was elaborated that was tested by academics and professionals of the area and after improvement used for the data collection in the companies. Some questions were based on the questionnaires of the Small Business Innovation survey conducted by Sebrae and the Innovation Survey 2014 (PINTEC), carried out by IBGE. The questions were structured in three blocks, the first deals with questions related to the general profile of the company, the second is related to Local Productive Arrangements and the third is innovation, which is the main part of the questionnaire.

- Delimitation of the sample: In order to study a sample of companies belonging to a cluster, it was decided to search for companies that were part of Local Productive Arrangements (LPAs) in the ABC region of São Paulo, Brazil. The sample within the LPA can be considered convenient, since it was composed by the respondent companies of the questionnaire. Responses were obtained from the following agglomerates: Tooling, Textile and of Clothing, Furniture and Cosmetics.

- Application of the questionnaire: For the application of the questionnaire, it was sent to the companies an invitation by email to participate in the research, in the emails was shared the link of the form that was made available electronically through the tool "Forms" of Google. The emails were sent twice to businesses with an interval of approximately two weeks. For the Cosmetics LPA, the counting was done through the mediation of the LPA coordinator, also by email.

- $\quad$ Data collection: The data were collected between March 23 and April 26, 2017 (34 days), through the electronic responses of the questionnaire.

- Data analysis: To analyze the data was used the Microsoft Excel 2016 tool that allowed the statistical analysis and the elaboration of graphs to help the results visualization. 


\subsection{Analysis of Results \\ Lines of Financing}

The following are the current government funding programs that support the innovation process in companies and include microenterprises and small businesses with their respective objectives. They are operated by the Brazilian Development Bank (BNDES), the Financier of Studies and Projects (Finep) and the Workers' Assistance Fund (FAT)

- BNDES Automatic (BNDES): Finance, through accredited Financial Institutions, investment projects or isolated working capital.

- BNDES Card(BNDES): Pre-approved credit for the acquisition of goods and services accredited in the BNDES Card Operations Portal.

- Exim Pre-shipment Innovative Company (BNDES): To increase the competitiveness of Micro, Small and Medium Enterprises (MSMEs) innovative companies by financing the export of information technology goods and services developed in Brazil, indicated in the List of Financial Products Applicable to the Lines of Export Financing BNDES Exim.

- FAT Inovacred (FAT): Financing projects of technological innovation of legal entities whose objective is to increase the competitiveness of companies.

- FAT Pro-innovation (FINEP): To finance pre-investment studies and projects to be carried out by Brazilian consulting engineering companies, whose purpose is to implement infrastructure works that provide higher quality of final products, greater production efficiency and the introduction of innovative products and processes.

- Finem - Innovation(BNDES): Financing investment in innovation.

- Inovacred Enterprises and Institution of Science and Technology (FINEP): Provide financing for application in the development of new products, processes and services, or in the improvement of existing ones, or in innovation in marketing or organizational innovation, aiming to increase the competitiveness of companies in the regional or national scope.

- Inovacred Expresso (FINEP): Financing innovative activities in companies and other institutions through the granting of resources in a simplified form, provided they meet the conditions established as framework requirements.

- Innovation in Assistive Technology (FINEP): To finance the technological development and innovation of products, processes and services for people with disabilities, the elderly and people with reduced mobility.

- Innovative MSME(BNDES):To increase the competitiveness of Micro, Small and Medium Enterprises (MSMEs), financing the necessary investments for the introduction of innovations in the market, articulated with the other actors of the National Innovation System.

- Procult(BNDES): To develop and strengthen productive chains of the culture economy in the country

\subsection{Survey}

For the accomplishment of the Field Survey, companies that belong to four local productive arrangements in the region of São Paulo ABC: Textiles and Clothing, Cosmetics, Tooling and Furniture were interviewed.

\section{Results}

Next, the results of the field research carried out with companies of the LPAs previously described will be presented. 254 companies were contacted and 23 companies responded 
(9.06\%), of these $16(6.30 \%)$ are in the profile of Microenterprise and Small Business, which are the focus of this research, thus composing the sample evaluated.

When evaluating the profile of the sample, it was observed that all the companies are active in the industry, of which $6 \%$ also work in commerce and services. This is probably due to the strong industrial character of the four LPAs studied. In relation to the size, $63 \%$ are Small Porte and $37 \%$ are micro enterprises, based on the classification of Sebrae by number of employees. The mean age of the sample is 19.1 years, this value can be considered relevant, since it characterizes companies that have survived even though they are of low size.

In absolute percentage the distribution of respondents among the LPAs studied was: Tooling: 37\%; Cosmetics: 31\%; Textiles and clothing: 19\%; Furniture maker: $13 \%$. Regarding the relative quantity of the number of responding companies of each LPA, it was obtained: Cosmetics 31.49\%; Textiles and clothing: 10.34\%; Tooling: 6.33\%; Furniture maker: $5.41 \%$. These data show that the LPA of tooling is composed of a larger number of companies, because even with few respondents it was the LPA with greater representation in the sample. A highlight can be given to LPAs of Cosmetics, which had almost a third of participation, this probably happened due to the intermediation of its coordinator.

Among the advantages of being included in the LPAs were the dissemination of knowledge, cooperation and competition, access to specialized services and greater exchange between customers and suppliers. Regarding the perception of innovation by companies, it was observed that companies in general value innovation and that there is somehow a positive vision in relation to this process, which has a more continuous character in the sample and a significant insertion in the culture of organizations.

When asked about the innovation practice, all the companies stated that they have already made some kind of innovation, considering the definition of the Oslo Manual in view of the subjectivity that the term has and the fact that even in the literature there is no consent for define what it means. In view of this, it can be inferred that the entire sample claims to have already implemented something new or significantly improved in the companies (product, process, marketing or management).

According to the Oslo Manual, the minimum requirement is that innovation is a novelty for the company, the degree of geographical innovation was verified and it was obtained: Only for the company: 19\%; Location: 19\%; Regional: $19 \%$; National: $31 \%$; Overall: $12 \%$. With this it is possible to observe that the innovations developed had a majority for the national level, which is a considerable scope.

In terms of collaboration, suppliers were listed as the main contributors to the innovation process, followed by customers or consumers. This result shows how the innovation process can have a strong link with good communication in the supply chain. Only three companies stated that they had not collaborated in the process, which shows that the partnerships were predominant for the accomplishment of the innovation, indicating the practice of open innovation.

For the investment in the innovation process, all companies stated that own resources were used in the innovation process, and the use of other resources was very low. Bank loans appear in second position, but with great difference compared to the first alternative. In addition, the fact that public financing has been little used by these companies is highlighted.

The high costs involved and the scarcity of appropriate sources of funding were the most pointed barriers by companies, these data show that financial issues are an objection for these companies to practice innovation and resembles data on the national profile of MSEs. Therefore, the focus given to this subject when it comes to the innovation process in small companies is shown to be relevant when considering this sample. 
The note that the companies gave to the government support in the innovation process, points out great dissatisfaction of practically all the companies. When this result is observed in parallel with all the practices of strengthening the National Innovation System that have been implemented by the government in the last decades, it is noticed that in general these companies have not perceived many positive impacts of this process.

When questioned about the knowledge of the financing lines studied in this study, it was observed that in general, there is great ignorance about the programs and even the companies that they know, and mostly do not use. The main exception is the BNDES card which is used by a considerable amount of the sample.

\section{Conclusion and Final Considerations}

The Micro and Small Companies have different participation in the international economies, but in general, their performance is remarkable. In Brazil, these companies began to gain notoriety a few decades ago, but gradually initiatives in favor of them have grown and important achievements have been achieved. For these companies, innovation has become a necessity; however, putting it into practice is not an easy process because they have to deal with several limitations, including financial limitations. Given this situation, the insertion in business alliances and the participation of the government can help in the development of innovative processes in the companies.

The survey of MSEs has shown that the financial difficulties have especially focused on the cost of innovation and the scarcity of appropriate sources of funding are the main barriers to innovation, this proves that financial constraints really are an impasse for innovation, but despite the difficulties reported, companies have shown that innovation is extremely relevant and that innovative projects have been developed. It should be noted that they have happened with partnerships, showing the importance of being inserted in organizations that promote coopetition and open innovation.

In addition, the existence of financing lines involving MSEs shows that there are initiatives by the government to invest in these organizations, however, the lack of knowledge of most credit lines by the sample reveals a possible deficiency in the dissemination of these programs. Part of the discontent of companies with the government may be associated with this ignorance of actions in favor of innovation that have been developed especially in the last two decades.

It should be considered that this research has limitations and the results obtained cannot be generalized, since the survey was done with a sample of convenience with low rate of respondents, making the generalization statistically wrong. Finally, to add to this research, studies that show the impact that the use of public financing programs can promote and the consequences that the restrictions of access and use can cause, may be relevant. In addition, a critical financial analysis of the programs listed and approaching the tax benefits that MSEs can enjoy with the practice of innovation would be relevant. 


\section{References}

i. Associação Brasileira de Normas Técnicas, 2012. Atividades para gestão da pesquisa, do desenvolvimento e da inovação (PD\&I) - Terminologia, Rio de Janeiro: ABNT.

ii. Banco Nacional de Desenvolvimento., 2017. BNDES Exim Pré-embarque Empresa Inovadora. [Online]

Available at: http://www.bndes.gov.br/wps/portal/site/home/financiamento/produto

[Accessed 13 February 2017].

iii. Banco Nacional de Desenvolvimento, 2016. Circular SUP/AOI $N^{O}$ 26/2016-BNDES. [Online] Available at: http://www.bndes.gov.br/wps/portal/site/home/instituicoes-financeirascredenciadas

[Accessed 8 February 2017].

iv. Banco Nacional de Desenvolvimento, 2017. BNDES Finem - Inovação. [Online] Available at: http://www.bndes.gov.br/wps/portal/site/home/financiamento/produto/bndesinovacao/

[Accessed 13 February 2017].

v. Banco Nacional de Desenvolvimento, 2017. BNDES Procult. [Online] Available at: $\quad$ http://www.bndes.gov.br/wps/portal/site/home/financiamento/produto [Accessed 13 February 2017].

vi. Banco Nacional de Desenvolvimento, 2017. Cartão BNDES. [Online] Available at: http://www.bndes.gov.br/wps/portal/site/home/financiamento/produto/cartaobndes/

[Accessed 8 February 2017].

vii. $\quad$ Banco Nacional de Desenvolvimento, 2017. Circular AEX No oo3/2017, de o6 de janeiro de 2017. [Online]

Available at: $\quad$ http://www.bndes.gov.br/wps/portal/site/home/financiamento

[Accessed 8 February 2017].

viii. Banco Nacional de Desenvolvimento, 2017. Circular SUP/AOI No O1/2017-BNDES, de 17 de janeiro de 2017. [Online]

Available at: http://www.bndes.gov.br/wps/portal/site/home/instituicoes-financeiras [Accessed 8 February 2017].

ix. $\quad$ Bouncken, R., Gast, J., Kraus, S. \& Bogers, M., 2015. Coopetition: a systematic review, synthesis, and future research directions. Review of Managerial Science, 9(3), pp. 577-601.

x. $\quad$ Carrijo, M., 2011. Inovação e relações de cooperação: uma análise sobre o Programa de apoio à pesquisa em empresas (PAPPE), Uberlândia, Brazil: Federal University of Uberlândia.

xi. Cassiolato, J. \& Lastres, H., 2003. O foco em arranjos produtivos e inovativos locais de micro e pequenas empresas. In: H. LASTRES, J. CASSIOLATO \& M. MACIEL, eds. Pequena Empresa: Cooperação e Desenvolvimento Local. Rio de Janeiro: Relume Dumará, pp. 21-34.

xii. Comissão Europeia, 2015. Guia do utilizador relativo à definição de PME, Luxemburgo: Serviço das Publicações da União Europeia.

xiii. $\quad$ Costa, M. \& Olave, M., 2014. Inovação em Micro e Pequenas Empresas: Uma Visão dos Agentes Locais de Inovação do Sebrae em Aracaju - SE, Goiânia, Brasil: Encontro de Estudos de Empreendedorismo e Gestão de Pequenas Empresas (EGEPE).

xiv. $\quad$ Empresas, S. B. d. A. à. M. e. P., 2014. Participação das Micro e Pequenas empresas na Economia Brasileira, Brasília: Sebrae.

xv. Financiadora de Estudos e Projetos., 2017. FAT- Fundo de Amparo ao Trabalhador. [Online] Available at: $\quad$ http://www.finep.gov.br/a-finep-externo/fontes-de-recurso/outras-fontes [Accessed 13 February 2017]. 
xvi. Financiadora de Estudos e Projetos, 2017. Inovação em Tecnologia Assistiva. [Online]

Available at: http://www.finep.gov.br/apoio-e-financiamento-externa

[Accessed 13 February 2017].

xvii. Financiadora de Estudos e Projetos, 2017. Manual Operacional de Orientação aos Agentes

Financeiros - Linha Inovacred. [Online]

Available at: https://www.finep.gov.br/images/apoio-e-financiamento

[Accessed 13 February 2017].

xviii. Financiadora de Estudos e Projetos, 2017. Manual Operacional de Orientação aos Agentes

Financeiros -Linha Inovacred Expresso. [Online]

Available at: https://www.finep.gov.br/images/apoio-efinanciamento

[Accessed 13 February 2017].

xix. $\quad$ Fundo de Amparo ao Trabalhador, 2013. Resolução $N^{o} 710$, De 22 de Maio de 2013. [Online] Available at: $\quad$ http://portalfat.mte.gov.br/codefat/resolucoes-2/resolucoes-por-assunto [Accessed 8 February 2017].

xx. Gast, J., Filser, M., Gundolf, K. \& S.Kraus, 2015. Coopetition research: towards a better understanding of past trends and future directions. International Journal of Entrepreneurship and Small Business, 24(4), pp. 492-521.

xxi. Gil, A. C., 2010. Como Elaborar Projetos de pesquisa. 5th ed. São Paulo: Atlas.

xxii. Global Entrepreneurship Monitor, 2016. Global report. [Online]

Available at: http://www.gemconsortium.org

[Accessed 30 August 2016].

xxiii. Instituto Brasileiro de Geografia e Estatística, 2013. Pesquisa de Inovação 2011, Brasília: IBGE.

xxiv. J.Tidd \& Bessant, J., 2015. Gestão da inovação. 5th ed. Porto Alegre: Bookman.

xxv. $\quad$ Lucafó, B., 2013. Financiamento à inovação no Brasil: participação das empresas nos recursos não reembolsáveis do FNDCT, Campinas, Brazil: Institute of Geosciences, State University of Campinas.

xxvi. Nalebuff, B. \& Brandenburger, A., 1997. Co-opetition: Competitive and cooperative business strategies for the digital economy. Strategy \& leadership, 25(6), pp. 28-33.

xxvii. Organização para Cooperação e Desenvolvimento Econômico, 2005. Manual de Oslo: Diretrizes para coleta e interpretações de dados sobre inovaçã. 3th ed. OCDE, Eurostat: Finep.

xxviii. Pereira, M. et al., 2009. Fatores de inovação para a sobrevivência das micro e pequenas empresas no Brasil. RAI-Revista de Administração e Inovação, 1(6), pp. 50-65.

xxix. Porter, M., 1999. Competição: Estratégias competitivas essenciais. 13th ed. Rio de Janeiro: Elsevier.

xxx. $\quad$ República Federativa do Brasil, 2006. Lei Complementar no 123, de 14 de dezembro de 2006.

[Online]

Available at: http://www.planalto.gov.br/ccivil 03/LEIS/LCP/Lcp123.htm\#art89 11/ [Accessed 16 June 2016].

xxxi. Rodrigues, T. et al., 2014. Interfaces e delimitações da orientação para a inovação de micro e pequenas empresas brasileiras. Teoria e Prática em Administração, 4(2), pp. 155-179.

xxxii. Serviço Brasileiro de Apoio às Micro e Pequenas Empresas, 2015. Participação das Micro $e$ Pequenas empresas na Economia Brasileira: Relatório Executivo, Brasília: Sebrae.

xxxiii. Silva, G. \& Dacorso, A., 2013. Inovação aberta como uma vantagem competitiva para a micro e pequena empresa. RAI Revista de Administração e Inovação, 10(3), pp. 251-269. 